\title{
Keywords Given by Authors of Scientific Articles in Database Descriptors
}

\author{
Isidoro Gil-Leiva \\ Faculty of Communication and Documentation, University of Murcia, Murcia, Spain. E-mail: isgil@um.es \\ Adolfo Alonso-Arroyo \\ Faculty of Medicine, University of Valencia, Valencia, Spain. E-mail: adolfo.alonso@uv.es
}

In this article, the authors analyze the keywords given by authors of scientific articles and the descriptors assigned to the articles to ascertain the presence of the keywords in the descriptors. Six-hundred forty INSPEC (Information Service for Physics, Engineering, and Computing), CAB (Current Agriculture Bibliography) abstracts, ISTA (Information Science and Technology Abstracts), and LISA (Library and Information Science Abstracts) database records were consulted. After detailed comparisons, it was found that keywords provided by authors have an important presence in the database descriptors studied; nearly $25 \%$ of all the keywords appeared in exactly the same form as descriptors, with another $21 \%$ though normalized, still detected in the descriptors. This means that almost $46 \%$ of keywords appear in the descriptors, either as such or after normalization. Elsewhere, three distinct indexing policies appear, one represented by INSPEC and LISA (indexers seem to have freedom to assign the descriptors they deem necessary); another is represented by $\mathrm{CAB}$ (no record has fewer than four descriptors and, in general, a large number of descriptors is employed). In contrast, in ISTA, a certain institutional code exists towards economy in indexing because $84 \%$ of records contain only four descriptors.

\section{Introduction}

Indexing is the procedure applied to the content of documents and the questions to select those concepts that best represent them, and thus facilitate storing and retrieval. The International Association for Standardization (ISO norm 5963; 1985) recommends that during analysis of text documents "special attention be paid" to titles, abstracts, summaries or content tables, introductions, opening paragraphs of chapters or sections, conclusions, illustrations, diagrams, tables and captions, and underlined or highlighted words or sentences.

Received December 22, 2005; revised September 19, 2006; accepted September 19, 2006

(C) 2007 Wiley Periodicals, Inc. • Published online 25 April 2007 in Wiley InterScience (www.interscience.wiley.com). DOI: 10.1002/asi.20595
A keyword(s) is "a word or group of words, possibly in lexicographically standardized form, taken out of a title or of the text of a document characterizing its content and enabling its retrieval" (ISO norm 5963; 1985).

Although not seeking to be exhaustive, we can point out that research into keywords has dealt with a variety of subject matter:

Retrieval efficiency:

- Gross and Taylor (2005), on the debate on whether it is necessary to assign subject headings in library catalogs or to use keywords for retrieval, studied what effect keywords have on retrieval if catalogs do not include the field subject heading.

- Taghva, Borsack, Nartker, and Condit (2004) explored the use of manually assigned keywords for query expansion with interactive tools.

- Voorbij (1998) analyzed the value of subject matter descriptors and keywords from titles in subject matter searches.

- Tillotson (1995) investigated the possibilities of OPAC (online public access catalog) interfaces for search by keywords and controlled vocabulary. They also performed several experiments on the relevance of searching by keywords.

Use by authors and editors:

- Hartley and Kostoff (2003) reviewed journals from various disciplines to verify which habitually provided keywords. They also asked 35 editors of scientific journals to explain the advantages and drawbacks of using keywords.

- Gbur and Trumbo (1995) put forward 10 recommendations for choosing suitable keywords for journal articles, along with suggestions for preparing informative titles and useful abstracts both for readers and database producers.

Meta-tag keywords:

- Craven $(2004,2005)$ studied meta-tag keywords of Web sites for the 19 languages most commonly present on the Web, and determined the effect of Web site edition tools on meta-tag keywords. 
- Alimohammadi (2004) calculated the presence of meta-tag keywords in 346 Web sites of Iran.

Automatic extraction:

- The use of different methodologies and algorithms to obtain keywords has been the subject of repeated research in recent decades (Boger, Kuflik, Shoval, \& Shapira, 2001; Jones \& Paynter, 2002; Lancheng, 2005; Turney, 2000).

Comparison of keywords in titles, abstracts, and texts with assigned descriptors:

- Ansari (2005) compared the descriptors assigned to 506 doctoral theses from the Department of Indexing of the Iran University Central Library using the keywords from the titles of the theses.

- Gil-Leiva and Rodríguez Muñoz (1997) compared keywords in titles and abstracts from 450 scientific articles from the sciences, social sciences, and medical sciences using the descriptors assigned in three Spanish databases maintained by professional indexers.

With the exception of our own article (Gil-Leiva \& Alonso-Arroyo, 2005), we do not know of any other research that deals with the function that keywords provided by authors of scientific articles may or may not perform in professional indexing. The interest in verifying this possible influence is twofold. First, we will gain more knowledge of the intellectual process utilized by indexers; this understanding could then be integrated into methodologies applied in automatic indexing, which uses rules taken from human indexers. Second, authors' keywords could be used as titles, abstracts, and texts for automatic indexing of articles.

In Gil-Leiva and Alonso-Arroyo (2005), we randomly selected 108 scientific journals that were proportionally distributed among Social Sciences and Humanities (36), Science and Technology (36), and Medical and Health Sciences (36). Ten articles from various years were randomly selected from the 108 publications. Our final working sample was 1,080 articles that fulfilled two conditions: They possessed keywords and they were included in the ISOC, ICYT, and IME ${ }^{1}$ databases. We subsequently contrasted the keywords provided by the authors of the articles with the assigned subject matter descriptors.

As we will see later, the results of this study show that the keywords given by the authors of scientific articles are

\footnotetext{
${ }^{1}$ These databases compile articles from the journals edited in Spain and they belong to the main research organization in Spain. El Consejo Superior de Investigaciones Científicas produces and distributes the ICYT (Science and Technology) database, which covers the period from 1979 to the present day. It indexes some 800 journals and incorporates more than 8,000 entries per year; the ISOC (Social Sciences and Humanities) database covers the period since 1975 and includes over 2,000 journals and 23,000 new references each year. Since 1971, the IME (Biomedicine) database has indexed 321 journals and has 200,000 entries. The three databases are maintained by professional indexers, specialized in each of the disciplines covered by the databases.
}

directly or indirectly present in the subject matter descriptors assigned by professional indexers. Nevertheless, we considered that it was necessary to carry out further experiments on international databases to confirm the results obtained.

Thus, the aim of this article is to calculate the direct (exact) presence or the indirect presence (after a minor normalization process) of the keywords given by the authors of scientific articles in the descriptors assigned by professional indexers. For this purpose, we chose the INSPEC (Information Service for Physics, Engineering, and Computing), CAB (Current Agriculture Bibliography), ISTA (Information Science and Technology Abstracts), and LISA (Library and Information Science Abstracts) international databases.

\section{Materials and Methods}

This study was carried out using 640 scientific articles that fulfilled two conditions: They possess keywords given by the authors and are indexed in the databases mentioned. The articles belong to disciplines included in four databases: INSPEC (physics, electrical and electronic engineering, computer sciences, etc.), CAB Abstract (agriculture, forestry, veterinary science, nutritional sciences, etc.), ISTA (information science and related disciplines), and LISA (libraries and information science). Appendix A gives the journals and the years used in the study; Appendix B gives the document numbers of the 640 articles used in the study.

A table was drawn up for each of the 32 journals selected with the descriptors assigned to the 640 articles in the INSPEC, CAB, ISTA, and LISA databases and the keywords given by the authors. The tables took the following structure:

Source: Minimum data for article identification, i.e., year, volume number, and first and last pages.

Keywords: List of the keywords provided given by the author.

Descriptors: List of the descriptors proposed by the indexers of each database; number of keywords given by the author.

Number of Kw Used: Number of keywords participating in the comparisons to find the exact coincidences and the normalizations between keywords and descriptors.

Number of descriptors: Number of descriptors proposed by the indexers of each database.

Coincidences: Number of keywords coinciding exactly with the descriptors.

Normalized: Number of keywords that evoke concepts, which also appear as descriptors and have apparently undergone only one normalization process.

Total: Sum of the number of coincidences and the number of normalizations.

Tables 1, 2, 3, and 4 show the procedure for gathering and comparing the keywords and descriptors. The author of the article noted in the first row of Table 1 gave four keywords (global register allocation; graph coloring; linear scan; binpacking) and the article was assigned three descriptors in the 
TABLE 1. INSPEC database.

\begin{tabular}{|c|c|c|c|c|c|c|c|c|c|}
\hline Sources & Articles & Keywords (KW) & Descriptors (DE) & $\mathrm{N}^{\mathrm{o}} \mathrm{Kw}$ & $\mathrm{N}^{\circ} \mathrm{Kw}$ used & $\mathrm{N}^{\mathrm{o}} \mathrm{DE}$ & Exact & Normalization & Total $\mathrm{C}+\mathrm{N}$ \\
\hline $\begin{array}{l}\text { Sigplan } \\
\quad \text { Notices }\end{array}$ & Traub. 1998 & $\begin{array}{l}\text { 1. Global register } \\
\text { allocation } \\
\text { 2. Graph } \\
\text { coloring } \\
\text { 3. Linear scan } \\
\text { 4. Binpacking }\end{array}$ & $\begin{array}{l}\text { 1. Graph-colouring } \\
\text { 2. Optimising-compilers } \\
\text { 3. Storage-allocation }\end{array}$ & 4 & 1 & 3 & 1 & 0 & 1 \\
\hline $\begin{array}{r}\text { Performance } \\
\text { Evaluation }\end{array}$ & Sheng. 2003 & $\begin{array}{l}\text { 1. Admission } \\
\text { control } \\
\text { 2. Negotiation } \\
\text { 3. Multimedia } \\
\text { systems } \\
\text { 4. Stochastic } \\
\text { Petri-net } \\
\text { 5. Queuing } \\
\text { theory }\end{array}$ & $\begin{array}{l}\text { 1. Multimedia-systems } \\
\text { 2. Performance-evaluation } \\
\text { 3. Petri-nets } \\
\text { 4. Quality-of-service } \\
\text { 5. Queuing-theory } \\
\text { 6. Stochastic-processes }\end{array}$ & 5 & 3 & 6 & 2 & 1 & 3 \\
\hline
\end{tabular}

Note. INSPEC $=$ Information Service for Physics, Engineering, and Computing.

TABLE 2. CAB Abstracts database.

\begin{tabular}{|c|c|c|c|c|c|c|c|c|c|}
\hline Sources & Articles & Keywords (KW) & Descriptors (DE) & $\mathrm{N}^{\circ} \mathrm{Kw}$ & $\mathrm{N}^{\circ} \mathrm{Kw}$ used & $\mathrm{N}^{\circ} \mathrm{DE}$ & Exact & Normalization & Total $\mathrm{C}+\mathrm{N}$ \\
\hline $\begin{array}{l}\text { Water. Air \& } \\
\quad \text { Soil } \\
\text { Pollution }\end{array}$ & $\begin{array}{c}\text { Papassiopi. } \\
1999\end{array}$ & $\begin{array}{l}\text { 1. EDTA } \\
\text { 2. heavy metals } \\
\text { 3. leaching } \\
\text { 4. lead } \\
\text { 5. soil remediation }\end{array}$ & $\begin{array}{l}\text { 1. removal } \\
\text { 2. heavy-metals } \\
\text { 3. calcareous-soils } \\
\text { 4. polluted-soils } \\
\text { 5. EDTA } \\
\text { 6. leaching } \\
\text { 7. soil } \\
\text { 8. zinc } \\
\text { 9. lead } \\
\text { 10. pollution }\end{array}$ & 5 & 4 & 10 & 4 & 0 & 4 \\
\hline $\begin{array}{l}\text { Journal of } \\
\text { Agricultural } \\
\text { And Food } \\
\text { Chemistry }\end{array}$ & $\begin{array}{c}\text { Hornero. } \\
2001\end{array}$ & $\begin{array}{l}\text { 1. spectrophometry } \\
\text { 2. capsicum annuum } \\
\text { 3. carotenoids } \\
\text { 4. paprika } \\
\text { 5. oleoresin } \\
\text { 6. quality }\end{array}$ & $\begin{array}{l}\text { 1. carotenoids } \\
\text { 2. chemical-composition } \\
\text { 3. determination } \\
\text { 4. methodology } \\
\text { 5. oleoresins } \\
\text { 6. paprika } \\
\text { 7. spectrophotometry } \\
\text { 8. Capsicum } \\
\text { 9. Capsicum-annuum }\end{array}$ & 6 & 5 & 9 & 5 & 0 & 5 \\
\hline
\end{tabular}

Note. $\mathrm{CAB}=$ Current Agriculture Bibliography.

TABLE 3. ISTA database.

\begin{tabular}{|c|c|c|c|c|c|c|c|c|c|}
\hline Sources & Articles & Keywords (KW) & Descriptors (DE) & $\mathrm{N}^{\circ} \mathrm{Kw}$ & $\mathrm{N}^{\circ} \mathrm{Kw}$ used & $\mathrm{N}^{\circ} \mathrm{DE}$ & Exact & Normalization & Total $\mathrm{C}+\mathrm{N}$ \\
\hline $\begin{array}{l}\text { Information } \\
\text { Processing \& } \\
\text { Management }\end{array}$ & $\begin{array}{l}\text { Wildemuth. } \\
2000\end{array}$ & $\begin{array}{l}\text { 1. Factual databases } \\
\text { 2. Medical students } \\
\text { 3. Problem solving } \\
\text { 4. Interface design }\end{array}$ & $\begin{array}{l}\text { 1. Computer-Interfaces } \\
\text { 2. Databases } \\
\text { 3. Information-Retrieval } \\
\text { 4. Medical-Students } \\
\text { 5. Problem-Solving } \\
\text { 6. Clinical-Experience } \\
\text { 7. Evaluation }\end{array}$ & 4 & 4 & 7 & 3 & 0.5 & 3.5 \\
\hline $\begin{array}{l}\text { Online } \\
\quad \text { Information } \\
\quad \text { Review }\end{array}$ & Fong. 2002 & $\begin{array}{l}\text { 1. Internet } \\
\text { 2. Research } \\
\text { 3. Electronic publishing } \\
\text { 4. Content analysis }\end{array}$ & $\begin{array}{l}\text { 1. Scholarly-communication } \\
\text { 2. Document-access } \\
\text { 3. Extracting } \\
\text { 4. Practical-methods }\end{array}$ & 4 & 0 & 4 & 0 & 0 & 0 \\
\hline
\end{tabular}

Note. ISTA $=$ Information Science and Technology Abstracts. 
TABLE 4. LISA database.

\begin{tabular}{|c|c|c|c|c|c|c|c|c|c|}
\hline Sources & Articles & Keywords (KW) & Descriptors (DE) & $\mathrm{N}^{\mathrm{o}} \mathrm{Kw}$ & $\mathrm{N}^{\circ} \mathrm{Kw}$ used & $\mathrm{N}^{\circ} \mathrm{DE}$ & Exact & Normalization & Total $\mathrm{C}+\mathrm{N}$ \\
\hline $\begin{array}{l}\text { Library Acquisitions: } \\
\text { Practice \& Theory }\end{array}$ & Shirk. 1994 & $\begin{array}{l}\text { 1. Outsourcing } \\
\text { 2. Processing } \\
\text { 3. Contracts } \\
\text { 4. Technical services }\end{array}$ & $\begin{array}{l}\text { 1. Technical-services } \\
\text { 2. Contracting-out } \\
\text { 3. Booksellers }\end{array}$ & 4 & 2 & 3 & 1 & 1 & 2 \\
\hline $\begin{array}{l}\text { International Journal } \\
\text { of Information } \\
\text { Management }\end{array}$ & $\begin{array}{l}\text { Loebbecke. } \\
1999\end{array}$ & $\begin{array}{l}\text { 1. Information services } \\
\text { 2. Electronic publishing } \\
\text { 3. Electronic commerce } \\
\text { 4. Multi-media }\end{array}$ & $\begin{array}{l}\text { 1. Electronic-publishing } \\
\text { 2. Evaluation } \\
\text { 3. Rentrop-Publishing }\end{array}$ & 4 & 1 & 3 & 1 & 0 & 1 \\
\hline
\end{tabular}

Note. LISA $=$ Library and Information Science Abstracts.

INSPEC database (Graph-colouring; Optimising-compilers; Storage-allocation). It can be observed that the keyword "Graph coloring" also appears as a descriptor, and hence, in the column Coincidence, there is a 1 because no normalization process appears for any of the keywords in the Descriptors, a 0 appears in the column Normalization. Hence, in the last column - the sum of Coincidence and Normalization - there is a 1.

The column Normalization quantifies to what extent one or several keywords proposed by an author evoke a concept later represented by one or more descriptors. We use the word evoke in the sense of reminding or bringing to mind. This may be total or partial, i.e., a keyword by an author may bring to mind a complete concept or just a part, or in other words, a complete descriptor or a part of one. A value of equal to 1 was assigned for a seemingly complete reminder between keyword and descriptor, and 0.5 was assigned when it was partial. Table 5 shows various examples of this and Table 6 gives the data for the journal Library Acquisitions Practice \& Theory and the LISA database.

TABLE 5. Examples of the use of 1 and 0.5 in the Normalization column.

\begin{tabular}{llc}
\hline Keywords from authors & \multicolumn{1}{c}{ Descriptors } & Normalization \\
\hline Internet & Internet & 1 \\
Libraries & Libraries & 1 \\
Parliament & Parliaments & 1 \\
Thesaurus construction & Thesauri Construction & 1 \\
Anglo-American Cataloguing & AACR & 1 \\
$\quad$ Rules & & \\
Cathode ray tube (CRT) & Cathode ray tube & 1 \\
$\quad$ display & displays & \\
Linear programming & Linear programming & 1 \\
Organic matter & Organic matter & 1 \\
Tomato & Tomatoes & 1 \\
Protein & Protein-content & 0.5 \\
Embryology & Embryos & 0.5 \\
Soil & Soil-pollution & 0.5 \\
Measurement & Statistics & 0.5 \\
Libraries & Digital-libraries & 0.5 \\
Cataloguing & Online-cataloguing & 0.5 \\
Departmental libraries & Academia-libraries & 0.5 \\
Democratization & Democracy & 0.5 \\
Red wine & Wines & 0.5 \\
\hline
\end{tabular}

\section{Results and Discussion}

Before presenting the results, it should be explained that the 24 journals studied here were reviewed to read the recommendations on keywords in the Instructions to Authors. In general, three to six keywords that cover the main issues dealt with in the article are recommended. One of the journals includes the indication "which should complement the title but not repeat words in it." Appendix C shows the most important of these.

\section{Quantitative Relation Between the Number of Keywords Given by Authors and by Descriptors}

According to the data obtained, authors usually respect the guidelines in the Instructions to Authors, as is confirmed in summarized form in Table 7 and in greater detail in Appendix D. As mentioned, three to six words is the recommendation, although some authors include up to 20.

With regard to the descriptors assigned in the various databases, significant variations do appear for several aspects. The total number of descriptors assigned is relatively similar in INSPEC (775), ISTA (646), and LISA (780); however, in contrast 1955 descriptors are assigned in $\mathrm{CAB}$, much more than twice the number assigned in the other databases. The number of descriptors used per article differs likewise, which could be due to different indexing policies. Although the number of entries examined is not high, three apparent models of indexing are discerned. A first model in INSPEC and LISA, which leads to the indexing of $90 \%$ of the articles with between 2 and 9 descriptors; a second model, represented by CAB, where no article has fewer than four descriptors assigned to it, there is a compact band that has between 6 and 14, and then a substantial number from 15 up to 35 descriptors (there are 2 articles with 31 and 35 , respectively.). Finally, the third model belongs to ISTA, where there seems to be a certain economy in the indexing because of the 160 entries, 135 have only four descriptors assigned to them.

In conclusion, these indexing policies mean that INSPEC, ISTA, and LISA have an average of 4-5 descriptors per article, whereas in $\mathrm{CAB}$ the average stands at 12 descriptors. See Appendix D for details. 
TABLE 6. Data obtained for the journal Library Acquisitions Practice \& Theory.

\begin{tabular}{lccccccccc}
\hline Article & \# Kw & \# Kw Used & \# DE & Exact & Normal & Total E+N & \% Exact & \% Normal & $\%$ Total \\
\hline 1 & 4 & 1 & 2 & 0 & 1 & 1 & 0.00 & 25.00 & 25.00 \\
2 & 5 & 3 & 4 & 1 & 1.5 & 2.5 & 20.00 & 30.00 & 50.00 \\
3 & 4 & 3 & 4 & 1 & 2 & 3 & 25.00 & 50.00 & 75.00 \\
4 & 4 & 2 & 3 & 1 & 1 & 2 & 25.00 & 25.00 & 50.00 \\
5 & 3 & 3 & 8 & 1 & 2 & 3 & 33.33 & 66.67 & 100.00 \\
6 & 2 & 1 & 3 & 0 & 1 & 1 & 0.00 & 50.00 & 50.00 \\
7 & 6 & 3 & 5 & 2 & 1 & 3 & 33.33 & 16.67 & 50.00 \\
8 & 5 & 2 & 6 & 2 & 0 & 2 & 40.00 & 0.00 & 40.00 \\
9 & 4 & 2 & 4 & 2 & 1 & 3 & 50.00 & 25.00 & 75.00 \\
10 & 3 & 2 & 3 & 0 & 1.5 & 1.5 & 0.00 & 50.00 & 50.00 \\
11 & 7 & 2 & 3 & 2 & 0.5 & 2.5 & 28.57 & 7.14 & 35.71 \\
12 & 4 & 2 & 4 & 1 & 0.5 & 1.5 & 25.00 & 12.50 & 37.50 \\
13 & 6 & 3 & 5 & 1 & 2 & 3 & 16.67 & 33.33 & 50.00 \\
14 & 4 & 3 & 7 & 1 & 1.5 & 2.5 & 25.00 & 37.50 & 62.50 \\
15 & 5 & 3 & 6 & 0 & 2 & 2 & 0.00 & 40.00 & 40.00 \\
16 & 4 & 2 & 8 & 0 & 2 & 2 & 0.00 & 50.00 & 50.00 \\
17 & 3 & 1 & 4 & 1 & 0 & 1 & 33.33 & 0.00 & 33.33 \\
18 & 7 & 2 & 2 & 2 & 0 & 2 & 28.57 & 0.00 & 28.57 \\
19 & 4 & 1 & 4 & 2 & 0 & 2 & 50.00 & 0.00 & 50.00 \\
20 & 4 & 2 & 7 & 2 & 0 & 2 & 50.00 & 0.00 & 50.00 \\
Total & 88 & 43 & 92 & 22 & 20.5 & 42.5 & & & \\
Mean & & $(48.86)$ & & & & & 24.19 & 25.94 & 50.13 \\
\hline
\end{tabular}

${ }^{\mathrm{a}}$ Descriptors assigned in the Library and Information Science Abstracts (LISA) database.

TABLE 7. Quantitative relation between keywords and descriptors.

\begin{tabular}{llcc}
\hline \multirow{2}{*}{ INSPEC } & & Keywords & Descriptors \\
\multirow{2}{*}{ CAB } & Total: & 730 & 775 \\
& Mean: & 4.6 & 4.9 \\
\multirow{2}{*}{ ISTA } & Total: & 841 & 1955 \\
& Mean: & 5.3 & 12.2 \\
\multirow{2}{*}{ LISA } & Total: & 724 & 646 \\
& Mean: & 4.5 & 4 \\
& Total: & 724 & 780 \\
& Mean: & 4.5 & 4.9 \\
\hline
\end{tabular}

Note INSPEC $=$ Information Service for Physics, Engineering, and Computing; $\mathrm{CAB}=$ Current Agriculture Bibliography; ISTA = Information Science and Technology Abstracts; LISA = Library and Information Science Abstracts.

\section{Semantic Relation Between the Number of Keywords Given by Authors and the Descriptors}

Tables $8,9,10$, and 11 provide examples that verify the lesser or greater presence of keywords in the descriptors. Table 12 shows the total data for the four databases.

In Gil-Leiva and Alonso Arroyo (2005), the data obtained for the three databases studied were as follows: in IME $64.96 \%$ of the keywords were present in the descriptors; in ISOC, the figure was $60.48 \%$, and ICYT was $58.18 \%$. In the present study, the results were CAB (60.8\%), LISA (42.2\%), INSPEC $(41.3 \%)$, and ISTA $(37.89 \%)$. Despite the lower percentages, our hypothesis that keywords provided by the authors are an important source for indexing articles is confirmed.
It is therefore of use to take into account the keywords of the authors both when teaching indexing and in efforts to automate this process. The algorithms used in automatic indexing analyze a structured text partially or completely to propose a list of terms, which represent the content of that text. These algorithms sometimes aim to simulate cognitive processes performed by human indexers, e.g., by giving more or less value to a word according to its position. This is the recommendation of ISO norm 5963/1985 devoted to "Methods for examining documents, determining their subjects, and selecting indexing terms." Simulating intellectual procedures, automatic indexing systems are traditionally based on three sources to identify and value words or sentences, i.e., the titles of papers, the abstracts, and the complete texts.

To the best of our knowledge, a review of the literature on automatic indexing does not reveal cases where keywords from the authors are used as a source. Titles have been dealt with by Kishida (2001); abstracts by Hmeidi, Kanaan, and Evens (1997) and Ripplinger and Schmidt (2001); and titles and abstracts by Hersh and Hickam (1992) and Silvester, Genuardi, and Klingbiel (1994). Complete texts have been studied by Gil-Leiva (1999, 2003), Montejo Ráez (2002), and Ko, Park, and Seo (2004).

SISA (system Interface search assistance) is an automatic indexing system (Gil-Leiva, 1999, 2003) that handles titles, abstracts, and complete text to propose indexing terms for the documents analyzed. From the results obtained here, it is our intention to carry out the necessary changes for SISA to be able to take into account keywords by the authors as well. We will thus ascertain if improvements in results arise from the inclusion of this source. 
TABLE 8. Presence of keywords in the INSPEC descriptors.

\begin{tabular}{|c|c|c|}
\hline Source & Keywords & Descriptors \\
\hline Low presence & 1. Global register allocation & 1. GRAPH-COLOURING \\
\hline Sigplan Notices & 2. Graph coloring & 2. OPTIMISING-COMPILERS \\
\hline Source: 2000, 35(9), 23-33 & $\begin{array}{l}\text { 3. Linear scan } \\
\text { 4. Binpacking }\end{array}$ & 3. STORAGE-ALLOCATION \\
\hline High presence & 1. Random-transform & 1. COMPUTATIONAL-COMPLEXITY \\
\hline Theoretical Computer Science & 2. Discrete inverse problem & 2. DISCRETE-TRANSFORMS \\
\hline Source: 2002 & 3. Discrete tomography & 3. INVERSE-PROBLEMS \\
\hline $281(1-2), 455-469$ & $\begin{array}{l}\text { 4. Contingency table } \\
\text { 5. Computational complexity } \\
\text { 6. Polynomial-time algorithmic } \\
\text { 7. NP-hard }\end{array}$ & 4. RANDOM-TRANSFORM \\
\hline
\end{tabular}

Note. INSPEC $=$ Information Service for Physics, Engineering, and Computing.

TABLE 9. Presence of keywords in the CAB Abstracts descriptors.

\begin{tabular}{lll}
\hline Source & \multicolumn{1}{c}{ Keywords } & \multicolumn{1}{c}{ Descriptors } \\
\hline Low presence & 1. LDL & 1. CARDIOVASCULAR-DISEASES \\
Annual Review of Nutrition & 2. Genetics & 2. DIETARY-CARBOHYDRATE \\
Source: 2001, 21, 283-295 & 3. Diet & 3. DIETARY-FAT \\
& 4. Subclass & 4. DIETS \\
& 5. Coronary disease & 5. FOOD-INTAKE \\
& & 6. GENES \\
& & 7. HEART-DISEASES \\
& & 8. LOW-DENSITY-LIPOPROTEIN \\
& & 9. METABOLISM \\
High presence & & 10. REVIEWS \\
Water, Air \& Soil Pollution & & 11. RISK \\
Source: 2001, 132 (3-4), 215-231 & 12. MAN \\
& 1. PAHs Hetero-PAHs & 1. Aromatic-hydrocarbons \\
& 3. Soil & 2. Biodegradation \\
& 5. Metabolites & 3. Composts \\
& & 4. Metabolites \\
& & 5. Polycyclic-hydrocarbons \\
& & 7. Soil \\
& & 8. Toxicity \\
\hline
\end{tabular}

Note. $\mathrm{CAB}=$ Current Agriculture Bibliography.

TABLE 10. Presence of keywords in the ISTA descriptors.

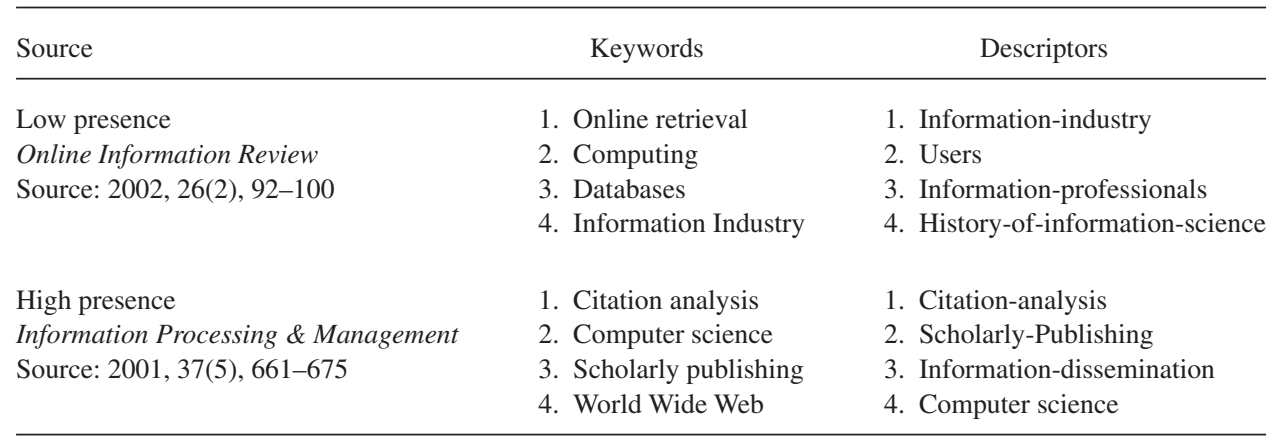

Note. ISTA $=$ Information Science and Technology Abstracts. 
TABLE 11. Presence of keywords in the LISA descriptors.

\begin{tabular}{lll}
\hline Source & \multicolumn{1}{c}{ Keywords } & \multicolumn{1}{c}{ Descriptors } \\
\hline Low presence & 1. Indexes & 1. Subject-indexing \\
Journal of Documentation & 2. Information retrieval & 2. Fiction \\
Source: 2002, 58(1), 49-65 & & $\begin{array}{l}\text { 3. Consistency } \\
\text { 4. Users }\end{array}$ \\
& & 5. Library-staff \\
High presence & 6. Public-libraries \\
Online Information Review & 1. Chemistry & 1. Online databases \\
Source: 2001, 25(4), 257-266 engines & 3. Hazardous materials & 2. Occupational health \\
& 4. Internet & and safety \\
& & 3. Chemistry \\
& & 4. Hazardous materials \\
& & 5. Internet \\
& & 7. World Wide Web
\end{tabular}

Note. LISA = Library and Information Science Abstracts.

TABLE 12. Presence of keywords in the descriptors.

\begin{tabular}{|c|c|c|c|c|c|c|}
\hline & Articles analyzed & \# of Keywords ${ }^{\mathrm{a}}$ & $\#$ of Descriptors ${ }^{\mathrm{b}}$ & Exact presence as $\%^{c}$ & Normalizations as $\%^{\mathrm{d}}$ & Total $\%^{\mathrm{e}}$ \\
\hline $\mathrm{CAB}$ & 160 & 841 & 1955 & 43.49 & 17.09 & 60.58 \\
\hline LISA $^{\mathrm{f}}$ & 160 & 724 & 780 & 23.00 & 19.52 & 42.52 \\
\hline INSPEC & 160 & 730 & 775 & 11.34 & 30.28 & 41.62 \\
\hline ISTA $^{\mathrm{f}}$ & 160 & 724 & 646 & 20.51 & 17.38 & 37.89 \\
\hline Mean & & & & 24.59 & 21.07 & 45.66 \\
\hline
\end{tabular}

Note. $\mathrm{CAB}=$ Current Agriculture Bibliography; LISA $=$ Library and Information Science Abstracts; INSPEC $=$ Information Service for Physics, Engineering, and Computing; ISTA = Information Science and Technology Abstracts.

${ }^{\text {a}}$ Keywords provided by authors of the 160 artícles.

${ }^{\mathrm{b}}$ Total number of descriptors assigned by the indexers to the 160 artícles.

${ }^{\mathrm{c}}$ Exact coincidence as \% between the keywords of the authors and the indexers' descriptors.

${ }^{\mathrm{d}}$ Keywords submitted to normalization process (e.g., ISTA: Text retrieval $\rightarrow$ INFORMATION-RETRIEVAL;

LISA: Text retrieval $\rightarrow$ ONLINE-INFORMATION-RETRIEVAL).

${ }^{\mathrm{e}} \mathrm{Sum}$ of total $\%$ of Exact $+\%$ Normalizations.

${ }^{\mathrm{f}}$ The same articles were used.

\section{Conclusions}

Several aspects have come to light in this study. First, there is a vacuum in the literature regarding the role that keywords provided by authors of scientific articles do or do not play in the subsequent indexing of the texts. It has been seen that studies on keywords have dealt mainly with the efficiency of information retrieval, its use by authors and editors, the use of meta-tag keywords or automatic extraction from texts. Second, although the number of entries studied is not large, three indexing policies have been detected: one in which the indexer appears to be free to assign descriptors that he or she deems appropriate (INSPEC and LISA); a second one, represented by $\mathrm{CAB}$, in which, in general, a large number of descriptors is employed (in some cases up to 35); and, finally, a certain type of institutional economy in indexing, with $84 \%$ of the entries analyzed having only four descriptors.

Finally, the keywords given by the authors have an important presence in the database descriptors. Twenty-five percent of all keywords handled in this study appear in exactly the same form as descriptors, whereas another $21 \%$ although they have undergone a normalization process, are still detected in the descriptors. This leads to around $46 \%$ of the keywords in the four databases appearing in the same or a normalized form as descriptors. These data confirm our results given in an earlier study (Gil-Leiva \& Alonso Arroyo, 2005), which means that keywords provided by authors are a valuable source of information for both human indexing and for automatic indexing systems of journal articles.

\section{References}

Alimohammadi, D. (2003). Meta-tag: A means to control the process of Web indexing. Online Information Review, 27(4), 238-242.

Ansari, M. (2001). Descriptors and title keywords: Matching in medical $\mathrm{PhD}$ dissertations. Quarterly Journal of the National Library of the Islamic Republic of Iran, 12(2), 23-33. 
Boger, Z., Kuflik, T., Shoval, P., \& Shapira, B. (2001). Automatic keyword identification by artificial neural networks compared to manual identification by users of filtering systems. Information Processing and Management, 37(2), 187-198.

Craven, T. (2004). Variations in use of meta tag keywords by web pages in different languages. Journal of Information Science, 30(3), 268-279.

Craven, T. (2005). Web authoring tools and meta tagging of page descriptions and keywords. Online Information Review, 29(2), 129-138.

Gbur, E.E., \& Trumbo, B.E. (1995). Key words and phrases-The key to scholarly visibility and efficiency in an information explosion. The American Statistician, 49, 29-33.

Gil-Leiva, I., \& Rodríguez Muñoz, J.V. (1997). Análisis de los descriptores de diferentes áreas del conocimiento indizadas en bases de datos del CSIC. Aplicación a la indización automática [Descriptors analysis on different knowledge areas in CSIC databases. Application on automatic indexing]. Revista Española de Documentación Científica, 20(2), $150-161$.

Gil-Leiva, I. (1999). La automatización de la indización de documentos [Automatic indexing documents]. Gijón, Spain: Trea.

Gil-Leiva, I. (2003, September). Sistema para la Indización Semi-Automática (SISA) de Artículos de Revista de Biblioteconomía y Documentación [Semiautomatic indexing system for journal papers in information science]. Paper presented at the II Jornadas de Tratamiento y Recuperación de Información, Leganés (Madrid), Spain.

Gil-Leiva, I., \& Alonso Arroyo, A. (2005). La relación entre las palabras clave aportadas por los autores de artículos de revista y su indización en las Bases de datos ISOC, IME e ICYT [Relationship between authors' keywords in journal papers and indexing terms in databases ISOC, IME and ICYT]. Revista Española de Documentación Científica, 28(1), 62-79.

Gross, T., \& Taylor, A.G. (2005). What have we got to lose? The effect of controlled vocabulary on keyword searching results. College \& Research Libraries, 66(3), 212-230.

Hartley, J., \& Kostoff, R.N. (2003). How useful are 'key words' in scientific journals? Journal of Information Science, 29(5), 433-438.

Hersh, W.R., \& Hickam, D.H. (1992). A comparison of retrieval effectiveness for three methods of indexing medical literature. The American Journal of the Medical Sciences, 303, 293-300.

Hmeidi, I., Kanaan, G., \& Evens, M. (1997). Design and implementation of automatic indexing for information retrieval with Arabia documents.
Journal of the American Society for Information Science, 48(10), $867-881$.

International Association for Standardization (ISO). (1985). Documentation. Methods for examining documents, determining their subjects, and selecting indexing terms (ISO 5963:1985). Geneva, Switzerland: Author.

Jones, S., \& Paynter, G.W. (2002). Automatic extraction of document keyphrases for use in digital libraries: Evaluation and applications. Journal of the American Society for Information Science and Technology, 53(8), 653-677.

Kishida, K. (2001). Statistical methods for automatically assigning classification numbers and descriptors based on title words of journal articles. Journal of Japan Society of Library and Information Science, 47(2), 49-66.

Ko, Y., Park, J., \& Seo, J. (2004). Improving text categorization using the importance of sentences. Information Processing \& Management, 40(1), $65-79$.

Lancheng, W. (2005). Theme information extraction of XMARC based on extended maximum matching algorithm. Journal of the China Society for Scientific and Technical Information, 24(1), 82-86.

Montejo Ráez, A. (2002, May). Towards conceptual indexing using automatic assignment of descriptors. Paper presented at the Workshop in Personalization Techniques in Electronic Publishing on the Web: Trends and Perspectives, Málaga, Spain.

Ripplinger, B., \& Schmidt, P. (2001). AUTINDEX: An automatic multilingual indexing system. In W.B. Croft, D.J. Harper, D.H. Kraft, \& J. Zobel (Eds.), SIGIR 2001: Proceedings of the 24th Annual International ACM SIGIR Conference on Research and Development in Information (p. 452). New York: SIGIR/ACM.

Silvester, J.P., Genuardi, M.T., \& Klingbiel, P.H. (1994). Machine-aided indexing at NASA. Information Processing \& Management, 30(5), 631-645.

Taghva, K., Borsack, J., Nartker, T., \& Condit, A. (2004). The role of manually-assigned keywords in query expansion. Information Processing \& Management, 40, 441-458.

Tillotson, J. (1995). Is keyword searching the answer? College and Research Libraries, 56(3), 199-206.

Turney, P.D. (2000). Learning algorithms for keyphrase extraction. Information Retrieval, 2(4), 303-336.

Voorbij, H.J. (1998). Title keywords and subject descriptors: A comparison of subject search entries of books in the humanities and social sciences. Journal of Documentation, 54(4), 466-476.

\section{Appendix A}

Journals and years.

\begin{tabular}{|c|c|c|c|}
\hline Database & Journals & Years & Papers \\
\hline \multirow[t]{8}{*}{ INSPEC } & Computer Methods and Programs in Biomedicine & $2004,2003,2002,2001,2000$ & 20 \\
\hline & Computerized Medical Imaging and Graphics & $2004,2003,2002,2001,2000$ & 20 \\
\hline & Computing & 2004, 2003, 2001, 1999, 1997, 1995, 1993 & 20 \\
\hline & Performance Evaluation & $2004,2003,2002,2001,2000$ & 20 \\
\hline & SIAM Journal on Computing & 2004, 2003, 2001, 1999, 1997, 1995, 1993 & 20 \\
\hline & Sigplan Notices & $2004,2002,2000,1998$ & 20 \\
\hline & Telematics and Informatics & $2004,2003,2002,2001,2000$ & 20 \\
\hline & Theoretical Computer Science & 2004, 2002, 2000, 1998 & 20 \\
\hline \multirow[t]{8}{*}{$\mathrm{CAB}$} & Agriculture and Human Values & $2004,2003,2002,2001,2000$ & 20 \\
\hline & Annual Review of Nutrition & $2004,2003,2002,2001,2000$ & 20 \\
\hline & Environmental Biology of Fishes & $2004,2003,2002,2001,2000$ & 20 \\
\hline & Environmental Geochemistry and Health & $2004,2003,2002,2001,2000$ & 20 \\
\hline & European Journal of Nutrition & 2003, 2002, 2001, 1999 & 20 \\
\hline & Journal of Agricultural and Food Chemistry & 2002, 2001, 2000, 1999, 1998 & 20 \\
\hline & Water, Air \& Soil Pollution & 2003, 2002, 2001, 2000, 1999 & 20 \\
\hline & Water Resources Management & 2003, 2002, 2001, 2000, 1999 & 20 \\
\hline \multirow[t]{4}{*}{ ISTA } & Cataloging \& Classification Quarterly & 2001, 1999 & 20 \\
\hline & Information Processing \& Management & 2001,2000 & 20 \\
\hline & International Journal of Information Management & 2003, 2002, 2001, 1999 & 20 \\
\hline & Journal of Documentation & 2002 & 20 \\
\hline
\end{tabular}


Journals and years. (Continued)

\begin{tabular}{llll}
\hline Database & \multicolumn{1}{c}{ Journals } & \multicolumn{1}{c}{ Years } & Papers \\
\hline & Library Acquisitions: Practice \& Theory & $1998,1996,1995,1994$ & 20 \\
& Library Collections, Acquisitions \& Technical Services & $2001,2000,1999$ & 20 \\
& Online Information Review & $2002,2001,2000$ & 20 \\
& The Electronic Library & 2001,2000 & 20 \\
LISA & Cataloging \& Classification Quarterly & 2001,1999 & $20^{*}$ \\
& Information Processing \& Management & 2001,2000 & $20^{*}$ \\
& International Journal of Information Management & $2003,2002,2001,1999$ & $20^{*}$ \\
& Journal of Documentation & 2002 & $20^{*}$ \\
& Library Acquisitions: Practice \& Theory & $1998,1996,1995,1994$ & $20^{*}$ \\
& Library Collections, Acquisitions \& Technical Services & $2001,2000,1999$ & $20^{*}$ \\
Online Information Review & $2002,2001,2000$ & $20^{*}$ \\
The Electronic Library & 2001,2000 & $20^{*}$ \\
& & Total Articles & 640 \\
\hline
\end{tabular}

Note. These articles are the same as those used to compare the keywords with the descriptors in the ISTA (Information Science and Technology Abstracts) database.

\section{Appendix B}

Document number of the articles in the databases.

ISTA

2901030;2902351;2902353;2903830;2903831;2903832;2903833;3000404;3002690;3002691;3003662;3003663;3102709;3102710;3102711;3304224;330 4243;3306036;3306037;3306050;3402758;3402977;3402980;3500289;3500846;3500848;3500867;3500951;3501025;3501200;3501226;3501382;3501467; $3501468 ; 3501474 ; 3501592 ; 3501619 ; 3501682 ; 3501691 ; 3501699 ; 3501728 ; 3501801 ; 3501877 ; 3501898 ; 3501905 ; 3502023 ; 3502120 ; 3502478 ; 3502794 ; 350$ $2908 ; 3503771 ; 3503815 ; 3503903 ; 3503975 ; 3503980 ; 3503996 ; 3600172 ; 3600251 ; 3600311 ; 3600621 ; 3600683 ; 3601288 ; 3601327 ; 3601404 ; 3601452 ; 360161$ 4;3601760;3601989;3602017;3602030;3602063;3602136;3602198;3602201;3602684;3602753;3602857;3602893;3603195;3603372;3603452;3603519;37 00246;3700304;3700417;3700489;3700517;3700521;3700659;3700780;3700797;3700878;3700950;3700951;3700952;3700961;3700962;3700980;37009 81;3701060;3701222;3701232;3701395;3701399;3701680;3701711;3702039;3702254;3702411;3702503;3702707;3702710;3702741;3702782;3702785; $3702822 ; 3702864 ; 3702985 ; 3703029 ; 3703057 ; 3703168 ; 3703170 ; 3703172 ; 3703175 ; 3703308 ; 3703416 ; 3703892 ; 3703899 ; 3703925 ; 3703972 ; 3703979 ; 380$ 0039;3800102;3800127;3800149;3800518;3800615;3800619;3801024;3801224;3801274;3801337;3802655;3803495;3804250;3804254;3900022;EJ6183 29;EJ633003;EJ606816;EJ606818;EJ606784;EJ605358;EJ605357;EJ605356;EJ605364;EJ606787;EJ606786;EJ605363;EJ605361

LISA

2401070;2411817;2411819;2416838;2416839;2416840;2416841;2425816;2425817;2428709;2428710;2429830;2439531;2439532;2439533;2465669;246 $5670 ; 2468652 ; 2468653 ; 2468655 ; 3215418 ; 3215419 ; 3218188 ; 3440438 ; 3441301 ; 3441302 ; 3441303 ; 3441306 ; 3441308 ; 3441309 ; 3447417 ; 3447418 ; 344741$ $9 ; 3447420 ; 3453825 ; 3453826 ; 3453830 ; 3453831 ; 3454179 ; 3454180 ; 3454181 ; 3454182 ; 3454184 ; 3454186 ; 3454252 ; 3456134 ; 3456136 ; 3456137 ; 3456147 ; 34$ $56149 ; 3456150 ; 3458220 ; 3458221 ; 3458222 ; 3458354 ; 3460468 ; 3460469 ; 3460470 ; 3462008 ; 3462010 ; 3462011 ; 3463939 ; 3463940 ; 3464228 ; 3464229 ; 34642$ 30;3465568;3465569;3465570;3474088;3474403;3474549;3474560;3475603;3475627;3475628;3477231;3477232;3477819;3478109;3479626;3479627; $3481557 ; 3481770 ; 3482475 ; 3485433 ; 3485434 ; 3485435 ; 3486256 ; 3486617 ; 3498336 ; 3498342 ; 3498371 ; 3502016 ; 3502017 ; 3502018 ; 3502019 ; 3502020 ; 350$ $2021 ; 3502029 ; 3502395 ; 3502396 ; 3502411 ; 3505606 ; 3507641 ; 3507642 ; 3507643 ; 3507644 ; 3507645 ; 3507646 ; 3507647 ; 3507652 ; 3509910 ; 3510112 ; 351011$ $3 ; 3510114 ; 3512619 ; 3512620 ; 3515829 ; 3516447 ; 3516448 ; 3516449 ; 3516451 ; 3516452 ; 3516453 ; 3516454 ; 3516455 ; 3516456 ; 3516457 ; 3516458 ; 3518083 ; 35$ 19759;3519957;3519960;3519961;3710476;3710477;3710478;3710511;3790658;3790659;3790905;3790906;3790907;3823633;3823634;3823635;3824075; $3824076 ; 3824077 ; 3824260 ; 3828112 ; 3831955 ; 3833090 ; 3833092 ; 3834294 ; 3481558 ; 3463941 ; 3505605 ; 3505608$

INSPEC

4411592;4411598;4411601;4643668;4643669;4892490;4892492;4941455;4941458;4945306;4945311;4945313;5479784;5479785;5532651;5532655;553 $2657 ; 5546819 ; 5978044 ; 5978056 ; 5978062 ; 6052758 ; 6052759 ; 6052763 ; 6082448 ; 6082450 ; 6095133 ; 6095135 ; 6381161 ; 6381163 ; 6381165 ; 6471658 ; 647166$ $0 ; 6531104 ; 6531106 ; 6531335 ; 6531336 ; 6531338 ; 6557340 ; 6557342 ; 6557343 ; 6572942 ; 6577788 ; 6591136 ; 6591137 ; 6623752 ; 6623754 ; 6656175 ; 6656177 ; 67$ $18086 ; 6718090 ; 6776200 ; 6776205 ; 6776231 ; 6776232 ; 6776236 ; 6798985 ; 6798986 ; 6840222 ; 6840226 ; 6840280 ; 6840282 ; 6854974 ; 6854975 ; 6887969 ; 68879$ $71 ; 6888173 ; 6888175 ; 6888178 ; 6915242 ; 6915244 ; 6944702 ; 6944703 ; 6959979 ; 6959980 ; 6959982 ; 6967310 ; 6967318 ; 7047932 ; 7047934 ; 7047937 ; 7047938 ; 7$ 227286;7227288;7250446;7250449;7256753;7256754;7283503;7283504;7308850;7308854;7322750;7322751;7372753;7372754;7372765;7407093;7407 $095 ; 7434750 ; 7434753 ; 7434754 ; 7522303 ; 7522305 ; 7537268 ; 7537272 ; 7567650 ; 7567653 ; 7567659 ; 7607407 ; 7607409 ; 7624203 ; 7624207 ; 7680369 ; 7680371 ;$ $7737123 ; 7737125 ; 7747619 ; 7747620 ; 7756546 ; 7756548 ; 7822815 ; 7822816 ; 7856994 ; 7856996 ; 7893564 ; 7893565 ; 7893567 ; 7915552 ; 7948440 ; 7996894 ; 799$ 6897;8013494;8016528;8018227;8018228;8018234;8018238;8022764;8022766;8025083;8026854;8026857;8073372;8073375;8132714;8162652;8170681; $8170682 ; 8177749 ; 8177750 ; 8181573 ; 8188014 ; 8188017 ; 8214533 ; 8214534 ; 8224592 ; 8224594 ; 8242702 ; 8242704$

(Continued) 


\section{CAB Abstracts}

19981418346;19981418347;19981418348;19981418349;19990303175;19990303176;19990303177;19991903782;19991903783;19991903784;19991906 $904 ; 19991910409 ; 19991910410 ; 19991910411 ; 20000110662 ; 20000311965 ; 20000311966 ; 20000311967 ; 20000311968 ; 20000402958 ; 20001415197 ; 20001$ 415198;20001415199;20001415200;20001910155;20003003119;20003007753;20003007755;20003007757;20003007758;20003021330;20003033319;20 003033322;20003033324;20003033327;20013001253;20013053731;20013095464;20013095470;20013095476;20013095478;20013122288;2001312229 $1 ; 20013122292 ; 20013122297 ; 20013132634 ; 20013132895 ; 20013132896 ; 20013132903 ; 20013132904 ; 20013148266 ; 20013148267 ; 20013148268 ; 2001314$ 8269;20013148534;20013148535;20013148536;20013148538;20013165074;20013165075;20013165077;20013165078;20013169370;20013169906;2001 $3171014 ; 20013171015 ; 20013171018 ; 20013171019 ; 20023005865 ; 20023011030 ; 20023014736 ; 20023014737 ; 20023014739 ; 20023014740 ; 20023017851 ; 2$ $0023017861 ; 20023017885 ; 20023089074 ; 20023089075 ; 20023089076 ; 20023125277 ; 20023125278 ; 20023125279 ; 20023125280 ; 20023140813 ; 200231528$ $88 ; 20023152889 ; 20023152890 ; 20023152891 ; 20023158858 ; 20023160381 ; 20023160382 ; 20023160383 ; 20023167023 ; 20023167024 ; 20023167997 ; 200231$ $67998 ; 20023167999 ; 20023168000 ; 20023198065 ; 20023198282 ; 20023198283 ; 20023198284 ; 20023198285 ; 20033002379 ; 20033002380 ; 20033002381 ; 200$ $33002382 ; 20033024560 ; 20033030479 ; 20033030480 ; 20033030481 ; 20033030482 ; 20033037233 ; 20033037235 ; 20033037236 ; 20033134940 ; 20033134941 ;$ 20033142542;20033142543;20033142544;20033142545;20033159928;20033159930;20033159931;20033159932;20033173145;20033173146;20033191 836;20033191837;20033209800;20033209801;20033215939;20033215940;20033215941;20033215942;20043000064;20043000065;20043011891;20043 011893;20043026335;20043026336;20043026337;20043026478;20043113950;20043113951;20043113952;20043113953;20043134370;20043155315;20 043155316;20043155317;20043155318;20043179911;20043179912;20043179913;20043179915;20043185163;20043213155;20043213160

Note. ISTA $=$ Information Science and Technology Abstracts; LISA = Library and Information Science Abstracts; INSPEC $=$ Information Service for Physics, Engineering, and Computing; $\mathrm{CAB}=$ Current Agriculture Bibliography.

\section{Appendix C}

Relating to the keywords in the instructions to authors of the journals.

\begin{tabular}{|c|c|c|}
\hline & Journals & Author instructions \\
\hline \multirow[t]{11}{*}{ INSPEC } & $\begin{array}{l}\text { Computer Methods and } \\
\text { Programs in Biomedicine }\end{array}$ & 3-6 key words for indexing purposes. \\
\hline & $\begin{array}{l}\text { Computerized Medical } \\
\text { Imaging and Graphics }\end{array}$ & $\begin{array}{l}\text { Key words: Enclose with each manuscript, at the end of the abstract, } 5-10 \text { key words. These terms } \\
\text { should be relatively independent (coordinate index terms), and as a group should optimally } \\
\text { characterize the paper. }\end{array}$ \\
\hline & Computing & $\begin{array}{l}\text { An AMS subject classification (primary, secondary) and suitable keywords and phrases should be given } \\
\text { on the title page. }\end{array}$ \\
\hline & Performance Evaluation & $\begin{array}{l}\text { Please add one to five keywords to your article. Keywords are essential for the accessibility and } \\
\text { retrievability of your article. Keywords assigned to articles will be assembled in a keyword index } \\
\text { which will be printed in the last issue of each volume, and in cumulative indexes. In addition, it is } \\
\text { planned to make keywords available on Internet. To maximize the consistency with which such } \\
\text { keywords are assigned by different authors, the following guidelines have been drawn up... }\end{array}$ \\
\hline & SIAM Journal on & 1993: A list of key words must accompany all articles \\
\hline & Computing & $\begin{array}{l}1999 \text { y 2004: Key words and AMS subject classifications: List of key words and AMS subject } \\
\text { classifications must accompany all articles. }\end{array}$ \\
\hline & Sigplan Notices & No mencionada nada sobre keywords. \\
\hline & Telematics and & 2000-2001-2002 : No menciona nada sobre keywords. \\
\hline & Informatics & $\begin{array}{l}\text { 2003-2004: Immediately after the abstract, provide 3-5 keywords, avoiding general and plural terms } \\
\text { and multiple concepts (avoid, for example, "and", "of"). Be sparing with abbreviations: only } \\
\text { abbreviations firmly established in the field may be eligible. These keywords will be used for } \\
\text { indexing purposes. }\end{array}$ \\
\hline & $\begin{array}{l}\text { Theoretical Computer } \\
\text { Science }\end{array}$ & $\begin{array}{l}\text { 1998-2000: Check to see that you have listed } 3 \text { to } 5 \text { keywords (to be placed under the abstract). } \\
\text { Keywords are essential for the accessibility and retrievability of your article. }\end{array}$ \\
\hline & & $\begin{array}{l}\text { 2002-2004: Immediately after the abstract, provide a maximum of five keywords, using American } \\
\text { spelling and avoiding general and plural terms and multiple concepts (avoid, for example, 'and', 'of'). } \\
\text { Be sparing with abbreviations: only abbreviations firmly established in the field may be eligible. } \\
\text { These keywords will be used for indexing purposes. }\end{array}$ \\
\hline \multirow[t]{4}{*}{ CAB ABSTRACT } & $\begin{array}{l}\text { Agriculture and } \\
\text { Human Values }\end{array}$ & Submissions should include an abstract, not to exceed 250 words, a set of key words. \\
\hline & $\begin{array}{l}\text { Annual Review of } \\
\text { Nutrition }\end{array}$ & No mencionada nada sobre keywords. \\
\hline & $\begin{array}{l}\text { Environmental Biology } \\
\text { of Fishes }\end{array}$ & $\begin{array}{l}\text { Finally, at bottom of the page the key words (no more than six) in lower case which should complement } \\
\text { the title but not repeat words in it. }\end{array}$ \\
\hline & $\begin{array}{l}\text { Environmental } \\
\text { Geochemistry and } \\
\text { Health }\end{array}$ & ... and the principal Conclusions. This should be followed by Keywords. (See below.) \\
\hline
\end{tabular}


Relating to the keywords in the instructions to authors of the journals. (Continued)

\begin{tabular}{|c|c|c|}
\hline & Journals & Author instructions \\
\hline & $\begin{array}{l}\text { European Journal of } \\
\text { Nutrition }\end{array}$ & Below the abstract place about 5 key words \\
\hline & $\begin{array}{l}\text { Journal of Agricultural } \\
\text { and Food Chemistry }\end{array}$ & $\begin{array}{l}\text { 1998: Provide four or five keywords to aid the reader in literature retrieval. The keywords are published } \\
\text { immediately before the text for all papers and following the abstract (except for Rapid } \\
\text { communications). }\end{array}$ \\
\hline & & $\begin{array}{l}\text { 2000: Provide significant keywords to aid the reader in literature retrieval. The keywords are published } \\
\text { immediately before the text for all papers and following the abstract. }\end{array}$ \\
\hline & & $\begin{array}{l}\text { 2004: Provide significant keywords to aid the reader in literature retrieval. The keywords are published } \\
\text { immediately before the text, following the abstract. }\end{array}$ \\
\hline & $\begin{array}{l}\text { Water, Air \& Soil } \\
\text { Pollution }\end{array}$ & Please provide 5 to 10 key words or short phrases in alphabetical order. \\
\hline & $\begin{array}{l}\text { Water Resources } \\
\text { Management }\end{array}$ & $\begin{array}{l}\text { Key words supplied by the author should appear on a line following the abstract and will be used in a } \\
\text { short index at the end of each volume of the journal. The key words selected should be } \\
\text { comprehensive and subject specific. It is not necessary to list the subject area of the Journal's } \\
\text { coverage as a key word. Six to } 10 \text { key words should be sufficient to cover the major subjects of a } \\
\text { given paper, although more can always be supplied if the author deems it necessary. General terms } \\
\text { should not appear as key words, as they have little use as information retrieval tools. Please, choose } \\
\text { key words to be as specific as possible, and list the most specific first, proceeding to the most general last. }\end{array}$ \\
\hline \multirow[t]{8}{*}{ LISA ITSA } & $\begin{array}{l}\text { Cataloging \& Classification } \\
\text { Quarterly }\end{array}$ & $\begin{array}{l}\text { The keywords should be in the style of one of the major thesauruses [sic] ... the terminology selected } \\
\text { should be suitable for computer analysis. }\end{array}$ \\
\hline & $\begin{array}{l}\text { Information Processing \& } \\
\text { Management }\end{array}$ & Please also supply three to five keywords describing the main topics of the paper. \\
\hline & $\begin{array}{l}\text { International Journal of } \\
\text { Information Management }\end{array}$ & $\begin{array}{l}\text { Care should be taken to include up to five keywords suitable for indexing the article by computer } \\
\text { analysis. }\end{array}$ \\
\hline & Journal of Documentation & Up to six keywords should be included which encapsulate the principal subjects covered by the article. \\
\hline & $\begin{array}{l}\text { Library Acquisitions: } \\
\text { Practice \& Theory }\end{array}$ & $\begin{array}{l}\text { Care should be taken to include up to five keywords suitable for indexing the article by computer } \\
\text { analysis. }\end{array}$ \\
\hline & $\begin{array}{l}\text { Library Collections, } \\
\text { Acquisitions \& Technical } \\
\text { Services }\end{array}$ & Up to six keywords should be included which encapsulate the principal subjects covered by the article. \\
\hline & Online Information Review & Up to six keywords should be included which encapsulate the principal subjects covered by the article. \\
\hline & The Electronic Library & Five-six keywords that identify article content. \\
\hline
\end{tabular}

Note. ISTA = Information Science and Technology Abstracts; LISA = Library and Information Science Abstracts; INSPEC = Information Service for Physics, Engineering, and Computing; $\mathrm{CAB}=$ Current Agriculture Bibliography. 


\section{Appendix D}

\section{Detailed Quantitative Relation Between}

\section{Keywords and Descriptors}

INSPEC database.

\begin{tabular}{|c|c|c|c|c|c|c|}
\hline & Keywords & $\begin{array}{c}\text { \# of } \\
\text { articles }\end{array}$ & $\begin{array}{c}\text { Total } \\
\text { keywords }\end{array}$ & Descriptors & $\begin{array}{c}\text { \# of } \\
\text { articles }\end{array}$ & $\begin{array}{c}\text { Total } \\
\text { descriptors }\end{array}$ \\
\hline & 1 & 0 & 0 & 1 & 4 & 4 \\
\hline & 2 & 7 & 14 & 2 & 19 & 38 \\
\hline & 3 & 36 & 108 & 3 & 34 & 102 \\
\hline & 4 & 49 & 196 & 4 & 22 & 88 \\
\hline & 5 & 35 & 175 & 5 & 23 & 115 \\
\hline & 6 & 16 & 96 & 6 & 23 & 138 \\
\hline & 7 & 11 & 77 & 7 & 15 & 105 \\
\hline & 8 & 2 & 16 & 8 & 4 & 32 \\
\hline & 9 & 2 & 18 & 9 & 10 & 90 \\
\hline & 10 & 1 & 10 & 10 & 4 & 40 \\
\hline & 20 & 1 & 20 & 11 & 1 & 11 \\
\hline & & & & 12 & 1 & 12 \\
\hline Total & & 160 & 730 & & 160 & 775 \\
\hline Mean & & & 4.6 & & & 4.9 \\
\hline
\end{tabular}

Note. INSPEC $=$ Information Service for Physics, Engineering, and Computing.

CAB Abstracts database.

\begin{tabular}{|c|c|c|c|c|c|c|}
\hline & Keywords & $\begin{array}{c}\text { \# of } \\
\text { articles }\end{array}$ & $\begin{array}{c}\text { Total } \\
\text { keywords }\end{array}$ & Descriptors & $\begin{array}{c}\# \text { of } \\
\text { articles }\end{array}$ & $\begin{array}{c}\text { Total } \\
\text { descriptors }\end{array}$ \\
\hline & 1 & 0 & 0 & 1 & & \\
\hline & 2 & 1 & 2 & 2 & & \\
\hline & 3 & 12 & 36 & 3 & & \\
\hline & 4 & 35 & 140 & 4 & 1 & 4 \\
\hline & 5 & 55 & 275 & 5 & 4 & 20 \\
\hline & 6 & 30 & 180 & 6 & 8 & 48 \\
\hline & 7 & 16 & 112 & 7 & 12 & 84 \\
\hline & 8 & 5 & 40 & 8 & 15 & 120 \\
\hline & 9 & 4 & 36 & 9 & 17 & 153 \\
\hline & 10 & 2 & 20 & 10 & 11 & 110 \\
\hline & & & & 11 & 13 & 143 \\
\hline & & & & 12 & 17 & 204 \\
\hline & & & & 13 & 16 & 208 \\
\hline & & & & 14 & 9 & 126 \\
\hline & & & & 15 & 5 & 75 \\
\hline & & & & 16 & 6 & 96 \\
\hline & & & & 17 & 3 & 51 \\
\hline & & & & 18 & 4 & 72 \\
\hline & & & & 19 & 4 & 76 \\
\hline & & & & 20 & 4 & 80 \\
\hline & & & & 22 & 2 & 44 \\
\hline & & & & 23 & 1 & 23 \\
\hline & & & & 24 & 3 & 72 \\
\hline & & & & 26 & 2 & 52 \\
\hline & & & & 28 & 1 & 28 \\
\hline & & & & 31 & 1 & 31 \\
\hline & & & & 35 & 1 & 35 \\
\hline Total & & 160 & 841 & & 160 & 1955 \\
\hline Mean & & & 5.3 & & & 12.2 \\
\hline
\end{tabular}

Note. $\mathrm{CAB}=$ Current Agriculture Bibliography.
ISTA database.

\begin{tabular}{lcccccc}
\hline & & $\begin{array}{c}\text { \# of } \\
\text { articles }\end{array}$ & $\begin{array}{c}\text { Total } \\
\text { keywords }\end{array}$ & Descriptors & $\begin{array}{c}\text { \# of } \\
\text { articles }\end{array}$ & $\begin{array}{c}\text { Total } \\
\text { descriptors }\end{array}$ \\
& 1 & 0 & 0 & 1 & 0 & 0 \\
& 2 & 6 & 12 & 2 & 5 & 10 \\
& 3 & 25 & 75 & 3 & 7 & 21 \\
& 4 & 64 & 256 & 4 & 135 & 540 \\
& 5 & 38 & 190 & 5 & 4 & 20 \\
& 6 & 17 & 102 & 6 & 2 & 12 \\
& 7 & 4 & 28 & 7 & 5 & 35 \\
& 8 & 3 & 24 & 8 & 1 & 8 \\
& 10 & 1 & 10 & 10 & 1 & 10 \\
& 12 & 1 & 12 & & & \\
Total & 15 & 1 & 15 & & & \\
Mean & & 160 & 724 & & & \\
\hline
\end{tabular}

Note. ISTA $=$ Information Science and Technology Abstracts.

LISA database.

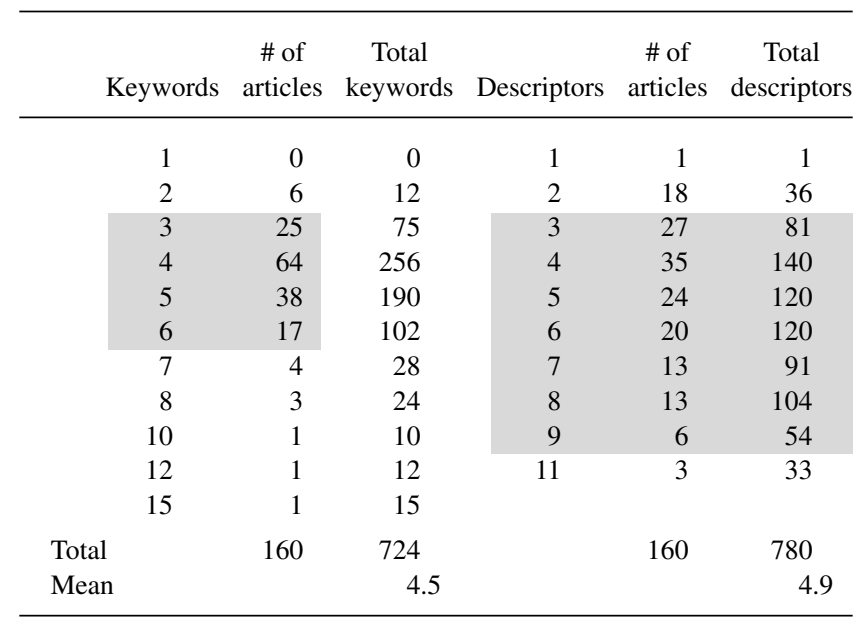

Note. LISA $=$ Library and Information Science Abstracts. 


\section{Appendix E}

Semantic relation between the keywords given by the authors and the indexers' descriptors.

\begin{tabular}{|c|c|c|c|c|c|}
\hline INSPEC & \# PC & $\%$ PC used & $\%$ DE exact & $\%$ DE norm & Total \% \\
\hline Computer Methods Programs in Biomedicine & 85 & 41.18 & 12.94 & 23.58 & 35.42 \\
\hline Computerized Medical Imaging and Graphics & 108 & 51.85 & 14.81 & 40.45 & 54.58 \\
\hline Computing & 82 & 51.22 & 8.75 & 37.32 & 46.07 \\
\hline Performance Evaluation & 92 & 46.74 & 9.67 & 39.58 & 48.00 \\
\hline SIAM Journal on Computing & 80 & 37.50 & 9.33 & 25.50 & 34.83 \\
\hline Sigplan Notices & 112 & 33.04 & 5.48 & 20.83 & 26.30 \\
\hline Telematics and Informatics & 89 & 57.30 & 23.17 & 31.58 & 54.13 \\
\hline Theoretical Computer Science & 82 & 39.02 & 6.60 & 23.43 & 30.02 \\
\hline Total & 730 & 357.85 & 90.74 & 242.27 & 329.36 \\
\hline Mean & 91.25 & 44.73 & 11.34 & 30.28 & 41.62 \\
\hline CAB Abstracts & \# PC & $\%$ PC used & $\%$ DE exact & $\%$ DE norm & Total \% \\
\hline Agriculture and Human Values & 117 & 66.67 & 46.27 & 20.21 & 62.46 \\
\hline Annual Review of Nutrition & 99 & 28.28 & 19.85 & 6.73 & 26.58 \\
\hline Environmental Biology of Fishes & 94 & 58.51 & 28.21 & 24.27 & 52.49 \\
\hline Environmental Geochemistry and Health & 103 & 66.02 & 53.18 & 15.34 & 66.43 \\
\hline European Journal of Nutrition & 99 & 68.69 & 52.19 & 11.51 & 63.70 \\
\hline Journal of Agricultural and Food Chemistry & 116 & 64.66 & 55.21 & 15.96 & 68.66 \\
\hline Water, Air and Soil Pollution & 104 & 69.23 & 54.78 & 19.85 & 72.96 \\
\hline Water Resources Management & 109 & 57.80 & 38.26 & 22.82 & 59.42 \\
\hline Total & 841 & 479.86 & 347.95 & 136.69 & 472.70 \\
\hline Mean & 105.1 & 59.98 & 43.49 & 17.09 & 60.58 \\
\hline ISTA & \# PC & $\%$ PC used & $\%$ DE exact & $\%$ DE norm & Total \% \\
\hline Cataloging \& Classification Quarterly & 119 & 35.29 & 22.43 & 12.79 & 35.22 \\
\hline Electronic Library, The & 94 & 44.68 & 16.42 & 18.92 & 35.33 \\
\hline Information Processing \& Management & 96 & 56.25 & 36.42 & 17.06 & 53.48 \\
\hline International Journal of Inform Management & 79 & 41.77 & 11.25 & 31.04 & 42.29 \\
\hline Journal of Documentation & 68 & 47.06 & 9.92 & 23.50 & 33.42 \\
\hline Library Acquisitions: Practice \& Theory & 88 & 42.05 & 26.81 & 13.29 & 40.10 \\
\hline Library Collec, Acquis \& Tech Services & 92 & 34.78 & 22.85 & 12.92 & 35.77 \\
\hline Online Information Review & 88 & 30.68 & 18.00 & 9.54 & 27.54 \\
\hline Total & 724 & 332.56 & 164.10 & 139.06 & 303.15 \\
\hline Mean & 90.5 & 41.57 & 20.51 & 17.38 & 37.89 \\
\hline LISA & \# PC & $\% \mathrm{PC}$ used & $\% \mathrm{DE}$ exact & $\%$ DE norm & Total \% \\
\hline Cataloging \& Classification Quarterly & 119 & 39.50 & 20.58 & 23.35 & 43.93 \\
\hline Electronic Library, The & 94 & 46.81 & 24.42 & 18.54 & 42.96 \\
\hline Information Processing \& Management & 96 & 50.00 & 25.75 & 24.19 & 49.94 \\
\hline International Journal of Inform Management & 79 & 40.51 & 25.00 & 10.00 & 35.00 \\
\hline Journal of Documentation & 68 & 50.00 & 26.67 & 15.83 & 42.50 \\
\hline Library Acquisitions: Practice \& Theory & 88 & 48.86 & 24.19 & 25.94 & 50.13 \\
\hline Library Collec, Acquis \& Tech Services & 92 & 46.74 & 13.55 & 27.46 & 41.01 \\
\hline Online Information Review & 88 & 37.50 & 23.83 & 10.83 & 34.67 \\
\hline Total & 724 & 359.92 & 183.99 & 156.14 & 340.14 \\
\hline Mean & 90.5 & 44.99 & 23.00 & 19.52 & 42.52 \\
\hline
\end{tabular}

Note. DE $=$ Descriptors; ISTA $=$ Information Science and Technology Abstracts; LISA $=$ Library and Information Science Abstracts; INSPEC = Information Service for Physics, Engineering, and Computing; $\mathrm{CAB}=$ Current Agriculture Bibliography. 